\title{
Demand-Supply Disparity: How to Design Smallholder Farmers-Friendly Microcredit?
}

\author{
A. K. M. Zahirul Haque
}

\begin{abstract}
Criticisms are aplenty that formal credit system such as microcredit is not inclusive to cater for the need of smallholder farmers. This paper analyses the existing literature to find out the limitation of microcredit to fulfil the need of smallholder farmers. The paper found that microcredit for smallholder farmers encompasses either ex ante flexibility or ex post flexibility. However, smallholder farmers need both ex ante and ex post flexibility due to their small, irregular and uncertain income. The current paper suggests that there is a need to revise existing microcredit modality by including both ex ante and ex post flexibility in order to make microcredit more inclusive for smallholder farmers.
\end{abstract}

Index Terms - Smallholder farmer, microfinance, ex ante, ex post, flexibility.

\section{INTRODUCTION}

Access to finance by smallholder farmers has been a global issue for many years. A lack of access to credit hinders productivity of smallholder farmers [1]. Morvant-Roux [2] found that only 5-6\% people who work in the agriculture sector in Asia and Africa have an account with formal banks. In other words, the involvement of formal banking institutions, thought to be the lifeline for smallholder farmers to gain access to formal finance, is not yet satisfactory. Several authors have highlighted a set of barriers for smallholder farmers in accessing credit from the formal banking sector. Critical among them is the lack of land ownership. In this context, a study by Deininger and Jin [3] revealed that a large number of smallholder farmers do not have the legal right to land and, consequently, are excluded from the formal financial system. Along the same line, Banerjee and Duflo [4] found that land is the only asset of smallholder farmers and land holding may be the only basis for having a loan from formal financial institutions. In addition, Binswanger and Deininger [5] pointed out that income volatility and remote location of households may create barriers to get loans from formal banking system.

Ideally, microfinance is supposed to address these barriers for smallholder farmers, as it resolves the collateral problem and helps to manage the cash-flow problem when income is irregular and unpredictable [6]. Further, microfinance is an effective tool to provide different financial services to the poor not served by the conventional banking sector.

However, several empirical studies found that smallholder farmers do not benefit from microfinance as credit rationing is common in rural areas [7], [8]. According to Weber and Musshoff [9], "For microfinance to be inclusive, in regards to agricultural microfinance there is a need to provide microfinance loans with added flexibility" (p. 256). So, the main reason behind this credit rationing is that the credit offered by Microfinance Institutions (MFIs) cannot meet the demand of small farmers due to its rigid modality. Therefore, the main objective of this paper is to see the limitation of product design, and explore the features that need to be included to cater for the demand of smallholder farmers.

My approach is twofold. First, I will try to highlight the demand side by analyzing the financial characteristics and the need of smallholder farmers. The main research question is: Considering the portfolio of smallholder farmers, why are not the existing credit products suitable for smallholder farmers? And the sub-question is: What are the features that need to be included with existing products in order to meet the latent need of smallholder farmers?

Then, this paper will also highlight the supply-side barriers in order to offer suitable agricultural credit to smallholder farmers. In this section, this paper will make an argument about the features that we should include by considering the demand of smallholder farmers, the associated risks and sustainability of the MFIs

The rest of this paper is presented in the following way: section II discusses the portfolio of smallholder farmers, section III provides diagnostic analyses of demand side, section IV analyses the supply side, section V discusses how to minimise demand- and supply-side disparity, and section VI concludes.

\section{PORTFOlio OF SMALlHOLdER FARMER}

Very few proxy indicators exist for distinguishing smallholders from farmers' community. Land is the only proxy indicator to separate smallholder farmers. According to the Food and Agricultural Organization [10], farmers having land less than threshold size can be considered as smallholder farmers. But the FAO did not specify any threshold size. More importantly, the FAO used terms like smallholder farmer, family farm and family farmer in the same undertone [11]. However, the World Bank defines smallholders as those having low asset base and owns less than two hectares of land [12]. The World Bank [12] also estimates that out of 2.2 billion rural agricultural households, 1.5 billion (500 million households) belong to smallholder households.

Even when we consider land holding as a proxy indicator, there are big differences among smallholder farmer community in terms of the land size, its quality as well as its location. For instance, the income of smallholder farmers who own 0.15 hectare of land is not comparable with those having land around 1.50 hectares. In addition, the 
productivity from two hectares of land in African countries is much less than that in Asia Pacific region. Finally, the location of the land is also very important. The productivity of the land that is affected by flood widely differs from that not affected by flooding.

Besides land holding, the use of family labour is another main characteristic of smallholder farmers. Djurfeldt [13] found that smallholder farmers have a crucial advantage of using family labour which should be used when defining them. In most cases, women and other family members participate actively in crop production. However, depending on availability of capital and land size, family labour is replaced with or supplemented by modern machinery, applying agrochemical and employing temporary labour [14].

Similar to other farmers, the income of smallholders depends on the seasonal cycle. Aksoy et al. [15] studied in 15 low-income countries and found that the share of income directly from agriculture (crop production and livestock rearing) is about $37 \%$ and is used mostly for household consumption. So, the substantial share of income of smallholder farmers comes from staple food production and livestock rearing. However, some smallholder farmers also produce cash crop to increase their income.

The above analyses show that there are clear differences among smallholder farmers in terms of land size, access to finance, and use of family labour. Anderson and Christen [16] emphasised the segmentation or categorisation of smallholder farmers in relation to their portfolio. They found that segmentation of smallholder farmers is challenging but contributory for assessing the need of agricultural-related financial services. Broadly, smallholder farmers can be divided as follows:

\begin{tabular}{|c|c|c|c|}
\hline Parameters & $\begin{array}{c}\text { Non-commercial/ } \\
\text { subsistnece } \\
\text { smallholder }\end{array}$ & $\begin{array}{c}\text { Semi } \\
\text { commercial } \\
\text { smallholder }\end{array}$ & $\begin{array}{l}\text { Commercial } \\
\text { smallholder }\end{array}$ \\
\hline Population & $\begin{array}{c}300 \text { million } \\
\text { smallholders }\end{array}$ & $\begin{array}{l}165 \text { million } \\
\text { smallholders }\end{array}$ & $\begin{array}{l}35 \text { million } \\
\text { smallholdrs }\end{array}$ \\
\hline Land size & $\begin{array}{c}0 \text { to } 1 \text { hectre of } \\
\text { land }\end{array}$ & 1-2 hectres & At least 2 hectres \\
\hline $\begin{array}{l}\text { Gender of } \\
\text { farmers }\end{array}$ & $\begin{array}{l}\text { Women more } \\
\text { likey to work }\end{array}$ & & $\begin{array}{c}\text { Women less likely } \\
\text { to work }\end{array}$ \\
\hline $\begin{array}{l}\text { Types of } \\
\text { crop }\end{array}$ & Staple & $\begin{array}{c}\text { Mostly } \\
\text { staple, some } \\
\text { cash crop }\end{array}$ & $\begin{array}{l}\text { Mostly cash crop, } \\
\text { some staple }\end{array}$ \\
\hline $\begin{array}{l}\text { Engagement } \\
\text { in the } \\
\text { market }\end{array}$ & $\begin{array}{l}\text { Susbsistence } \\
\text { farmer buy } \\
\text { additional food } \\
\text { from market }\end{array}$ & $\begin{array}{l}\text { Have } \\
\text { surplus food } \\
\text { which is } \\
\text { sold in } \\
\text { market }\end{array}$ & $\begin{array}{l}\text { Sell surplus food } \\
\text { in market and } \\
\text { involve in contract } \\
\text { farming (cash } \\
\text { crop) }\end{array}$ \\
\hline
\end{tabular}

Adopted from [16], [17].

The return from the agriculture production is quite important and critical for smallholder farmers. The Fondo de Desarrollo Local (FDL), a Nicaraguan MFI, conducted a survey to find out the return from different Income Generating Activities (IGAs). Done by Clients and Merchetti [18], the survey found that average annual return from agricultural activities was $30 \%$ to $100 \%$ and that from livestock activities $40 \%$ to $100 \%$. But in case of more intensified farming such as cattle raising and semi-industrial poultry, the annual rate of return was between $120 \%$ and $180 \%$. However, an annual rate of return from non-farm activities ranged from $120 \%$ to $250 \%$. So clearly, the return from agricultural activities is low.

Aksoy et al. [15] also found that smallholders are often involved in agriculture-related activities such as wage employment, which is highly uncertain, to cover their expenses. In this relation, Anderson and Ahmed [19] found that a greater part of smallholder farmers' net cash income comes from non-agricultural activities. So, smallholder farmers often migrate to the nearest town or city in search of odd jobs in non-farm sectors.

Hossain et al. [20] found that the income of per person tenant farmer in Bangladesh is USD 269, which is much lower than the national average income (USD 848). Similarly, Anderson and Learch [24] found that in Mozambique $57 \%$ smallholder households have annual income of less than USD 480 and another $43 \%$ smallholder farmers has annual income within USD 480-540. So, there are obvious differences in the income level of smallholder farmers between countries and within countries.

As smallholder farmers are mostly depended on agriculture, they are associated with different risks, which ultimately affect their lives and livelihoods. Dellien and Lynch [21] highlighted three types of risk and pointed out that climate risk (flood, drought, and salinity), production risk (pest \& diseases and lack of knowledge of farming, processing and storage) and market risk (price volatility) affect the annual return from farm productions and consequently the income of smallholder farmers.

From the above discussion, it is clear that the income of smallholder farmers comes from agricultural crop production, farm-related activities as well as non-farm activities. Still, a substantial portion of their income comes from agriculture where the return is minimal. The average income is lower than the national average. However, their income is also irregular because it is mostly depended on seasonal cycle and availability of odd jobs. It is also unpredictable due to the risks associated with agricultural activities. In short, the income level of smallholder farmers is low, irregular and uncertain [6].

To resolve the 'Triple Whammy' [6] situation, smallholder farmers may adopt a number of financial tools. Jamie Anderson and Wajiha Ahmed [19] found that smallholder farmers use a number of financial tools to manage their lives. However, the study also found that smallholder farmers in Mozambique, Tanzania and Pakistan use three, twelve and eighteen financial tools respectively to cope with risks and uncertainties.

Diagne and Zeller [23] found that a larger part of smallholder farmer community in developing countries remains outside the rural financial system. This is also evident in the survey conducted on smallholder farmers by the CGAP. The study reveals that $85 \%$ of the total smallholder farmers are excluded from the formal financial services and only $6 \%$ smallholder farmers have membership in MFIs, Savings and Credit Coperatives SOCIETY (SACCOS) and Credit unions [24]. So it is clear that very few smallholder farmers have access to microfinance. 


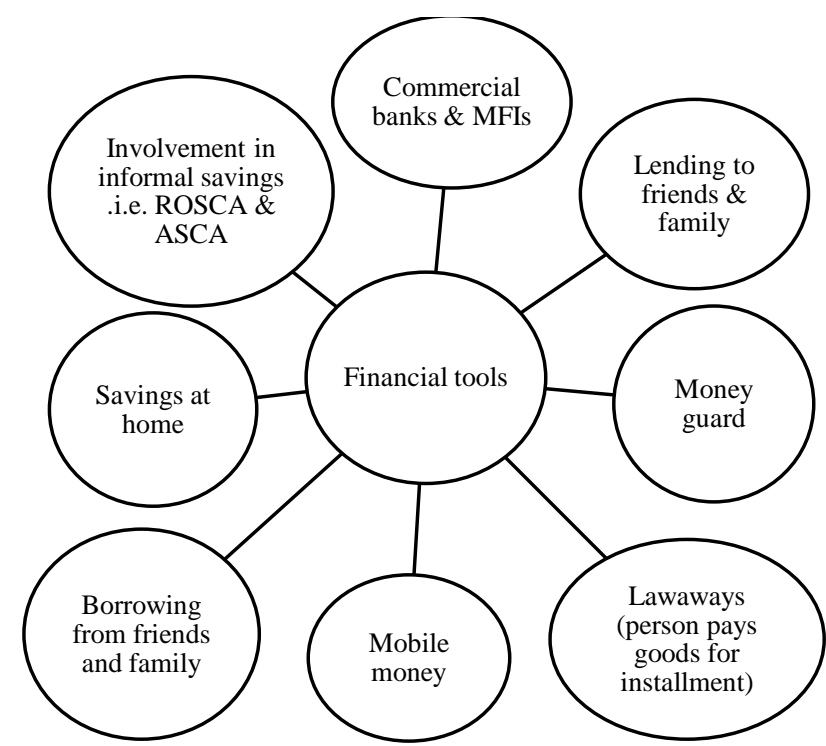

Fig. 1. Financial tools used by smallholder farmers Source: Adapted from [22] and the author's own contribution.

\section{Diagnostic ANALyses Of Demand SidE}

Burritt [25] highlighted that smallholder farmers need loan basically for two purposes: a) to meet the cost of agriculture production (input, wage of labour, irrigation) and b) to purchase agricultural machinery in order to increase productivity. However, the prime question is: Do standard products meet the demand of smallholder farmers?

Standard loan products of microfinance are based on frequent repayment [26]. As the income of small farmers is seasonal, the repayment of the standard loan is not adopted with the cash flow of smallholder farmers. So adding flexibility in the repayment system will cater for the credit need of small farmers. But the proxy question is: What types of repayment flexibilities in the product design do smallholder farmers need? To answer this question, we need to analyze the production cycle and the risks associated with the production cycle, which are as follows:

Based on the categorization, most of the smallholder farmers involve in staple food production in order to ensure food security. Semi-commercial and commercial smallholder farmers also engage in cash crop production. From the CGAP survey on smallholder diaries, Anderson and Ahmed [19] found that non-commercial farmers produce two crops annually but their sale is limited; semi-commercial farmers produce one crop annually but their sale varies; and commercial farmers produce two crops annually but they sell the crop immediately. So smallholder farmers prefer short (46 months) and medium (7-12 months) duration crop to meet household subsistence demand first and then to ensure quick cash flow. In short and medium duration crop production, smallholder farmers need credit, which has repayment facility based on the cash flow. These types of flexibility are referred to as ex ante flexibility, where repayments are adjusted with probable cash flow in the future [27], [28].

However, crop production is highly dependent on unpredictable climate risks (flood, drought) and production risks like pest attack [21]. These risks make small farmers more vulnerable because they do not have enough surplus to battle against sudden shocks. With a view to adopt these unpredictable risks, small farmers also need flexibility in rescheduling the loan. This provision of rescheduled loan is referred to as ex post flexibility where clients are allowed to reschedule existing repayment plan due to an unpredictable circumstance [27], [28].

So, a combination of both ex ante and ex post flexibility can meet the demand of smallholder farmers because either ex ante or ex post flexibility is not enough to meet their demand. It means smallholder farmers need repayment facility according to their cash flow and also need rescheduling facility in case of disasters.

Like any other farmer, smallholder farmers face market risks i.e. price volatility when they sell their crops, especially just after harvesting [21]. As smallholder farmers do not have sufficient surplus from previous years, they have to sell their produces just after harvesting to pay the loan and to start up another seasonal crop. But ex post flexibility does not consider the price volatility in the market. So farmers need flexibility in order to cope with price volatility and climate risks.

The interest rate of the loan is a critical issue for smallholder farmers. As agricultural finance is associated with high transaction cost [29], MFIs charge high interest rates for extending the loan to smallholder farmers. In this context, Briones [30] found that the demand of smallholder farmers becomes low among rice farmers in the Philippines when the lending rate is high. However, Diagne and Zeller [23] argue that the rate of interest is not an important factor for smallholder farmers to take loan; rather they consider the quality of services and variety of non-financial services.

The above analysis drives home the point that any one of the two provisions elaborately discussed in this paper, namely ex ante flexibility and ex post flexibility, cannot fully meet the demand of smallholder farmers; only a combination of the two can.

\section{SUPPLY-SIDE ANALYSES}

Providing inclusive microcredit is one of the greatest challenges for MFIs. Standard microcredit always caters for the need of the borrowers engaged in such non-farm activities requiring high cash flow. Generally, farmers have less stable sales and cash flow than their counterparts in the non-farm sectors. Moreover, farmers who are engaged in small-scale farming have lesser cash flow compared to other categories of farmers. In order to meet the demand of smallholders, following three major questions should be addressed to find out the suitable microcredit modality:

1) What types of flexibility are provided by the MFIs?

2) What are the risks associated if MFIs offer flexible loan products?

3) Does it affect the financial sustainability of the MFIs?

A review of different existing literature shows that MFIs provide either ex ante or ex post flexibility to farmers with some discipline device. For instance, Peruvian MFIs Confianza $^{2}$ provides seasonal loan with ex ante flexibility (repayment based on cash flow) and applies harsh penalty i.e. seizing of assets and high interest rates for the delay of

${ }^{2}$ http://www.confianza.pe 
repayment [27], [28]. On the other hand, the Bank of Agriculture and Agricultural Cooperatives (BAAC) ${ }^{3}$ provides short-, medium- and long-term loans to rural farmers with a provision for rescheduling the loan in case of climate risks [27]. However, the BAAC also verifies through its staff before rescheduling the loan, and charges high interests in case of moral hazards [31]. In both cases, Confianza and BAAC undertake additional enforcement mechanism in order to ensure financial discipline [28]. However, BAAC loan contract with rescheduling facility does not consider the price volatility of crops [28].

Labie, Laureti and Szafarz [27] and Hamp and Laureti [28] highlighted that Safesave ${ }^{4}$ works in the slum areas of Dhaka city and provides full flexibility of loan with no maturity and fixed repayment but applies three discipline devices i.e. savings as financial collateral, progressive lending to increase loan size and a frequent visit of payment collectors. To my knowledge, there is no MFI that provides fully flexible agricultural loan.

In answering the second question regarding risks of offering flexible loan products, Labie, Laureti and Szafarz [27] highlighted that MFIs may face three types of risks such as liquidity constraint, fraudulence activity of credit officers and moral hazard behaviour of clients when they offer flexible loan products. Firstly, loan rescheduling due to covariant risks [32] and low yield [33] can cause cash shortage to MFIs. Besides, flexible repayment may tempt credit officers to misappropriate cash [34]. Finally, rescheduling opportunity may increase the moral hazard behaviour of the client [35].

Sustainability becomes a major issue when MFIs offer loan for agricultural activities. Transaction costs and repayment performance are the key determinants to attain sustainability in agriculture finance. Moreover, additional enforcement mechanisms for extending flexible loan products also increases the transaction cost [28]. So flexible agricultural loan increases the transaction cost which persuades MFIs to increase the interest rate.

In addition, existing empirical evidence provide a mixed result on repayment performance when MFIs offer flexible loan. McIntosh [36] found improvement in repayment performance whereas Field et al. [37] found flexibility increases default rate. However, Hamp and Laureti (2011) analysed the BAAC financial report and found that PAR $>90$ is around $8 \%$ of the total outstanding. So flexible agriculture loan may increase moral hazard behaviour of the farmers which ultimately affects repayment performance and, consequently, the sustainability of the MFIs.

\section{MINIMISING DEMAND AND SUPPLY DISPARITY}

By analysing both demand and supply sides, the current paper found that smallholder farmers need loans with provisions for both ex ante and ex post flexibility. Besides, they require a provision for tackling price volatility situations. However, MFIs extend agricultural loan with a provision either for ex ante or ex post flexibility. Moreover, flexible loans are induced with some risks and therefore affect the sustainability of MFIs. So the question can be raised 'What are the possible ways to provide flexible loans to small farmers?' Based on my reviews, there are several directions to meet the credit demand of smallholder farmers.

Firstly, the 'Safesave' model may provide greater benefits to non-commercial and semi-commercial smallholder farmers. Due to full flexibility, smallholder farmers can repay the loan amount according to their cash flow and delay their repayment in case of price volatility, covariant risks and other income uncertainty. Moreover, it helps farmers to grow a savings mentality. My analyses also reveal that smallholder farmers use several savings insturment to manage their cash flow. From farmers' point of view, the only limitation is that the loan size is small in initial years. But farmers will get the bigger loans later through progressive lending incentives. From the supply-side perspective, MFIs will face less credit risk because clients are allowed to take loans based on their savings, and frequent visits of cash collectors also help to minimise moral hazard behaviour of clients [28]. However, the 'Safesave' model is successful in urban areas. There is a need for piloting this model in rural areas before replication.

Secondly, agricultural loan with ex ante flexibility is more suitable for commercial smallholder farmers because the farmers get the privilege to repay their loan based on their cash flow. Commercial smallholder farmers are better off than non-commercial and semi-commercial smallholder farmers. In this context, Hamp and Laureti [28] highlighted that Peruvian MFI Confianza targets better off farmers who have multiple sources of income so that farmers can repay the loan even in the case of crop failure. However, there is no alternative to crop insurance for smallholder farmers because one hazard in two or three years restrains them from fighting back the accompanied hardships and hence livelihood maintenance becomes quite impossible for them.

Finally, agriculture loans with only ex post flexibility is not suitable for smallholder farmers because it does not match with their cash flow.

My earlier discussion shows that interest rate of MFIs is high due to high transaction cost and MFIs face problems to attain sustainability when they provide flexible loans. As a solution, Peruvian MFI Confianza limits its portfolio to $25 \%$ in agriculture to manage their risks and cross-subsidise their operation cost [38].Therefore, diversification of the loan portfolio is one of the ways to retain the sustainability and ease interest rates. MFIs may start digital financial services in association with local mobile operators in order to decrease the transaction cost. In CGAP's survey on smallholder diaries, Anderson and Ahmed [19] found that a substantial portion of sample households (70\% in Pakistan, $56 \%$ in Tanzania and $46 \%$ in Mozambique) have at least one mobile phone but availability of digital financial services are limited. So there is a huge oppurtunity to extend digital financial services to decrease transaction cost.

\section{CONCLUSION}

The above review demonstrates that smallholder farmers are excluded not only from the commercial banking system 
but also from the MFIs. The repayment modality of the standard loan products does not allow farmers to repay the loan based on their cash flow as well as to minimize the risk related to the agricultural production cycle. The review further suggests that using the full flexibility model of 'Safesave', Bangladesh can meet the demand of its noncommercial and semi-commercial smallholder farmers. However, there is a need for piloting this model in rural areas as this model has been tested only in urban areas. Agriculture loan with ex ante flexibility can meet the demand of commercial smallholder farmers. But there is no alternative to crop insurance. My analyses also affirm that MFIs can offer flexible agricultural loans to smallholders incorporating some enforcement mechanisms in order to ensure financial disciplines. However, flexible loans have negative effects on sustainability due to poor repayment; they also increase the transaction cost due to the additional enforcement activities required to recover the loan. But MFIs can minimize this risk by diversifying its portfolio. To sum up, we can say that microfinance loan with the provision for flexibility intrinsically caters for the need of poor people like smallholder farmers. MFIs might fulfil their financial and social mission by serving poor people, including smallholder farmers.

\section{REFERENCES}

[1] Isaga, N. "Access to bank credit by smallholder farmers in Tanzania a case study", Africa Focus, Volume, 35, Nr. 1, pp 241-256, August 2018.

[2] Morvant-Roux, S. "Is Microfinance the Adequate Tool to Finance Agriculture.", in Beatriz, A. and Labie, M. The Handbook of Microfinance, World Scientific Publishing Co. Pte. Ltd, April 2011.

[3] Deininger, K. and Jin, R. "Tenure security and land-related investment: evidence from Ethiopia.", European Economic Revie, vol. 50, no. 5, pp. 1245-1277, 2006.

[4] Banerjee, A. and Duflo, E. "The economic lives of the poor.", Journal of Economic Perspect, vol. 21, no. 1, pp. 141-168, Winter 2007.

[5] Binswanger, H. and Deininger, K. "Explaining agricultural and agrarian policies in developing countries.", Economic Literature, vol. 35, pp. 1958-2005, February 1997.

[6] Collins, D., Morduch, J., Rutherford, S. and Ruthven, O. "Portfolios of the Poor: How the World's Poor Live on \$2 a Day", Princeton, NJ: Princeton Univ. Press, 2009.

[7] Reyes, A. and Lensink, R. "The credit constraints of market-oriented farmers in Chile", Journal of Development Studies, vol. 47, pp. 18511868, January 2011.

[8] Weber, R. and Musshoff, O. "Is agricultural microcredit really more risky? Evidence from Tanzania", Agricultural Finance Review, vol. 72 2012.

[9] Weber, R. and Musshoff, O. "Can flexible microfinance loans improve credit access for farmers?", Agricultural Finance Review, vol. 73, no. 2, pp. 255-271, 2013.

[10] Food and Agriculture Organization (FAO) "A data portrait of smallholder farmers", ROME, 2010.

[11] Food and Agriculture Organization (FAO). "International Year of Family Farming" April-May 2014 available at http://www.fao.org/family-farming-2014/en/

[12] World Bank "World Development Report 2007: Agricuture for Development". World Bank, Washiton DC: World Bank, 2008

[13] Djurfeldt, G. 'Defining and operationalizing family farming from a sociological perspective', Rural Sociology, vol. 36, pp. 340-351, December 1996.

[14] Kritzinger, A. and Vorster, J. "The Conceptualization of Farm Family Business: Deciduous Fruit Farming in South Africa.", Sociologia Ruralis, vol. 37, pp. 114-133, 1997.

[15] Aksoy, A., Javier, B., Covarrubias, K. and Zezza, A. "Household Income Structures in Low-income Countries", in Aksoy, A. and Hoekman, B. Food Prices and Rural Poverty, Washington, D.C: World Bank, May 2010.
[16] Anderson, J. and Christen, R.P. "Segmentation of Smallholder Households: Meeting theRange of Financial Needs in Agricultural Families", CGAP Focus Noe, vol. 85, April 2013.

[17] Delberg "Catalyzing Smallholder Agricultural Finance", New York: Delberg, September 2012

[18] Merchetti, P. "The Fonde de Desarrollo Local, an atypical MFI: the dream unleasing the potential of the peasantry and the praxis needed to acheive it.", Class lecture presented at European Microfinance Program (EMP) on November, 2015.

[19] Anderson, J. and Ahmed, W. "SMALLHOLDER DIARIES: Building the Evidence Base with Farming Families in Mozambique, Tanzania, and Pakistan", Consultative Group to Assist the Poor (CGAP), vol. Perspective 2, March 2016

[20] Hossain, M., Chakraborty, B., Jaim, W., Hossain, M.A., Malek, M. and Ahmed Md. Shakil, H. "Impact Assessment of Credit Programme for the Tenant Farmers:Baseline Report 2012, Dhaka: BRAC, 2012.

[21] Dellien, H. and Lynch, E. "Rural Finance for Small Farmers: An Integrated Approach", WWB Focus Note, 2007.

[22] Anderson, J. and Ahmed, W.) "Early Insight from Financial Diaries of Small holder Households", CGAP Focus Note, vol. 102, March 2015.

[23] Diagne, A. and Zeller, M. "Access to credit and its impact on Welfare in Malawi", International Food Policy Reseach Institute (IFPRI) Reseach Report, vol. Reseach Report:116, February 2001.

[24] Anderson, J. and Learch, C. "National Survey and Segmentation of Smallholder Households in Mozambique-Understanding Their Demand for Financial, Agricultural, and Digital Solutions", CGAP, March 2016.

[25] Burritt, K. Expanding Access To Financial Services In Malawi, New York: United Nations Capital Development Fund, March 2006.

[26] Armendariz, B. and Morduch, J. "Microfinance beyond group lending', Economics of Transition", vol. 8, pp. 401-420, 2000.

[27] Labie, M., Laureti, C. and Szafarz, A. "Discipline and Flexibility: A Behavioral Perspective on Product Design in Microfinance", $C E B$ Working paper, vol. 15/20, May 2015.

[28] Hamp, M. and Laureti, C. "Balancing flexibility and discipline in microfinance: Innovative financial products that benefit clients and service providers", CEB Working Paper, vol. 11/044, October 2011.

[29] Zeller, M. "Models of Rural Financial Institutions, Paving the Way Forward for Rural Finance: An International Conference on Best Practices" March 2008.

[30] Briones, R. "Do Small Farmers Borrow Less when the Lending rate Increases? The Case of Rice Farming in the Philippines", Munich Personal RePEc Archive, vol. 6044, December, 2007.

[31] Townsend, R.M. and Yaron, J. 'The credit risk-contingency system of an Asian development', Economic Perspectives, vol. QIII, pp. pp. 3148, 2001.

[32] Acharya, V.V., Almeida, H. and Campello, M. "Aggregate Risk and the Choice between Cash and Lines of Credit.", Journal of Finance, vol. 68, no. 5, pp. 2059-2116, May 2013.

[33] Karlan, D. and Mullainathan, S. "Is Microfinance too Rigid?" India: Centre for Micro Finance, Institute for Financial Management and Research, 2006.

[34] Jeon, D.-S., Menicucci and Domenico "When is the Optimal Lending Contract in Microfinance State Non-Contingent?', European Economic Review, vol. 55, no. 5, pp. 720-731, 2011.

[35] Boot, AWA. "Relationship Banking: What Do We Know?", Journal of Financial Intermediation 9 (1): 7-25., vol. 9, no. 1, pp. 7-25, January 2000.

[36] McIntosh, C. "Estimating Treatment Effects form Spatial Policy Experiments-An Application to Ugandan Microfinance. ', Review of Economics and Statistics, vol. 90, no. 1, pp. 15-18, February 2008.

[37] Field, E., Pande, R., Papp, J. and Rigol., N. "Does the Classic Microfinance Model Discourage Entrepreneurship among the Poor?", American Economic Review, vol. 103, no. 6, pp. 2196-2226, October 2013.

[38] Christen, R.P. and Pearce, D. 'Managing Risk and Designing product for agricultural microfinance: Features of an emerging model.', CGAP Occational paper, vol. 11, August 2005.

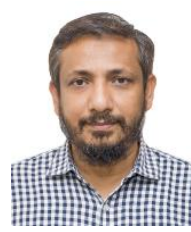

A K M Zahirul Haque completed his Bachelor and Master's degrees in Anthropology from the University of Dhaka, Bangladesh. He has a second Master's degree in Microfinance, which he completed in 2016 from the University Libre de Bruxelles, Brussels. Zahirul Haque is currently working as Manager at PKSF, an apex development organization in Bangladesh. 